\title{
Landscape Features and Processes Influencing Forest Pest Dynamics
}

\author{
Scott Ferrenberg ${ }^{1,2}$
}

Published online: 2 June 2016

(C) Springer International Publishing AG 2016

\begin{abstract}
Insects and pathogens (pests) in forest ecosystems can impact tree fitness and greatly increase rates of tree mortality. Pest dynamics vary significantly across spatial and temporal scales due to influences from a range of landscape features. Here, with a focus on recent research, primarily from coniferous forest ecosystems, I review the influence of landscape features and their interactions with global change pressures on forest pest dynamics. Landscape genetics have revealed evidence of local adaptation and spatially aggregated patterns in phenotypes within tree populations. Thus, I also consider the role of phenotypic adaptations as features of the landscape affecting forest pest dynamics. Landscape influences on pest dynamics are illustrated by three case-studies representing pests with different feeding strategies, levels of host-specialization, and dispersal potential. The effects of landscape features on forest pest-host interactions are anticipated to grow increasingly complicated in an era of rapid environmental change. Despite recent advances in remote sensing, genomics, and analytical tools, significant gaps remain in our understanding of the complex interactions of pest-host systems with landscape features under global change pressures. Filling these gaps requires continued research into the landscape ecology of forest pests, along with increased efforts to understand the role of pest and host functional traits
\end{abstract}

This article is part of the Topical Collection on Effects of Landscape Structure on Undesired/Over-Abundant Species and Ecological Processes

Scott Ferrenberg

scott.ferrenberg@colorado.edu

1 Department of Ecology and Evolutionary Biology, University of Colorado, Boulder, CO 80309, USA

2 Present address: Southwestern Biological Science Center, U.S. Geological Survey, Moab, UT 84532, USA in pest population dynamics. Thus, I conclude with a conceptual framework for generating testable hypotheses regarding factors affecting the relative influence of landscape features on forest pest dynamics and the predictability of spatiotemporal patterns in forest pest dynamics.

Keywords Climate change - Forest pests - Functional traits . Landscape ecology $\cdot$ Pathogens $\cdot$ Phenotypes $\cdot$ Spatial scale

\section{Introduction}

Forests cover $30 \%$ of the Earth's terrestrial surface and provide numerous ecological services $[1,2]$. Tree community structure is shaped by a number of spatially and temporally variable processes [1-4] which determine forest ecosystem functions. One such process is tree mortality [5]. Despite its ecological importance, tree mortality remains poorly understood due to the complex interactions of underlying physiological causes with environmental conditions [6,7]. Tree mortality is further complicated by interactions among trees and their natural enemies such as phytophagous insects and fungal pathogens ('pests'). In some cases, pests benefit directly (e.g., decreased generation times) and indirectly (e.g., increased susceptibility of hosts) from environmental change leading to amplified rates of tree mortality $[8,9]$. As a result, pest outbreaks in forest ecosystems have increased due to climate change, atmospheric pollution, species introductions, and land-use change [6, 7, 10-14].

Pests can impact forests across great spatiotemporal scales, as in the example of multi-decadal, continental-scale bark beetle epidemics in North American and European conifer forests (Fig. 1a) $[15,16]$. Pest occurrence patterns are often dictated by landscape features (Fig. 1b, c) [17], yet much of the foundational knowledge of forest pest dynamics is derived 


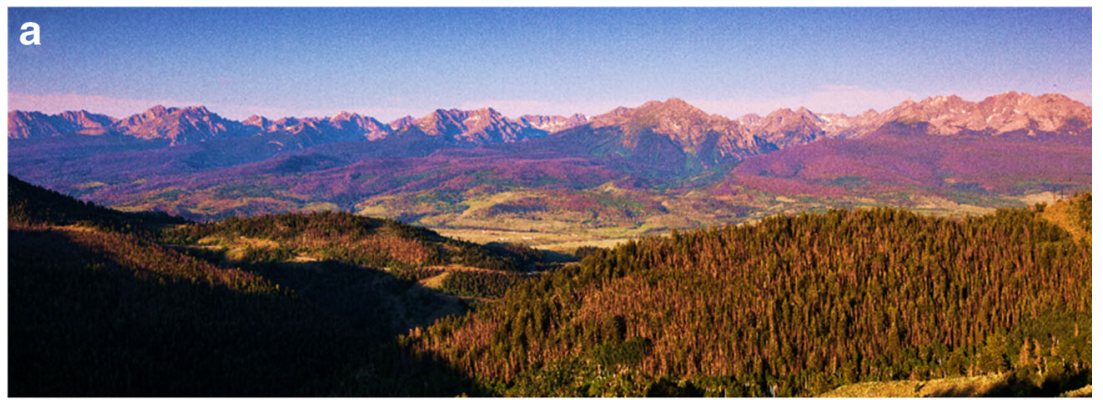

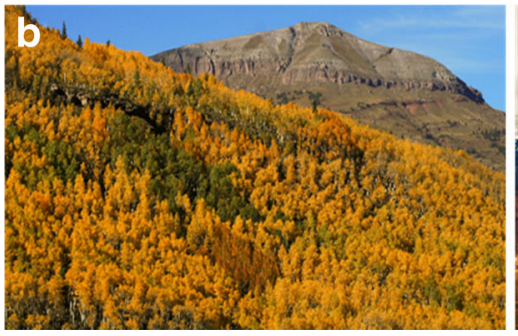

Fig. 1 Tree mortality from pests can occur over large spatiotemporal scales with variable influences of landscape features. Insect epidemics have affected millions of hectares of forests in temperature regions as in the case of the mountain pine beetle (Dendroctonus ponderosae) damage (red trees on the far valley slope) in northern Colorado, USA, shown in panel (a) (photo has been altered for increased color saturation to enhance visibility of dead trees). Tree genotypes and phenotypes, illustrated on a small scale in panel (b) with variable leaf change rates on different aspen

from studies of localized interactions among trees and pests over short timespans. Scaling this knowledge to the landscape level remains a great challenge, requiring the application of a landscape ecological approach to forest pathology and epidemiology (Fig. 2) [17-19]. Here, I review recent research, primarily from coniferous forests, linking landscape features to pest dynamics. Further, I consider the importance of interactions among landscape features and climate/atmospheric change, and the influence of host-tree phenotypes on pest dynamics. I use three case-studies to illustrate the complexity of landscape influences on pest dynamics. The first two draw upon disparate examples of an active-dispersing, native moth (jack pine budworm, Choristoneura pinus) that prefers to attack one species of pine versus a passively-dispersed, introduced fungal-pest (white pine blister rust, Cronartium ribicola) that can infect all species of the pine subgenera Strobus. The third case-study takes a broader view of several genera of native bark beetles that collectively represent a guild of pests affecting numerous tree species of the family Pineaceae. I conclude with a conceptual framework for linking pest traits to the relative influence of landscape features on forest pest dynamics.

Throughout this review, I use the word 'landscape' to refer not only to physical and spatial features and patterns, but also in reference to the mosaic of ecological and evolutionary processes that shape pest-host interactions. Indeed, pests and their tree hosts are increasingly demonstrated to be locally adapted to environmental pressures while still possessing traits linked to their deeper evolutionary and biogeographical history

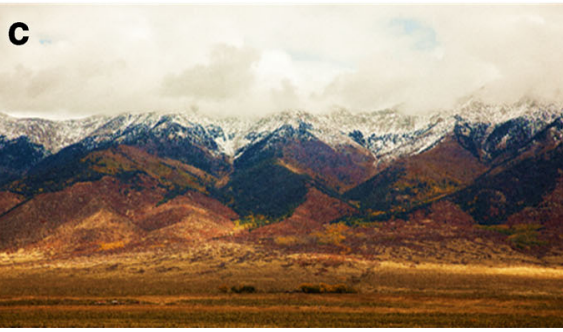

(Populus tremuloides) clones, are frequently spatially arranged on the landscape in relation to various features/processes with important consequences for forest pest dynamics. Forest pests can also be impacted by forest stand position on the landscape. For example, position in relation to elevation, aspect, and latitude can dramatically influence climate as demonstrated by the elevational-temperature cline and shift in tree cover on northern versus southern aspects of montane valleys in panel $(\mathbf{c})$

[20-22]. As a result, variation in host phenotypes are often distributed in spatial patterns discernible via landscape

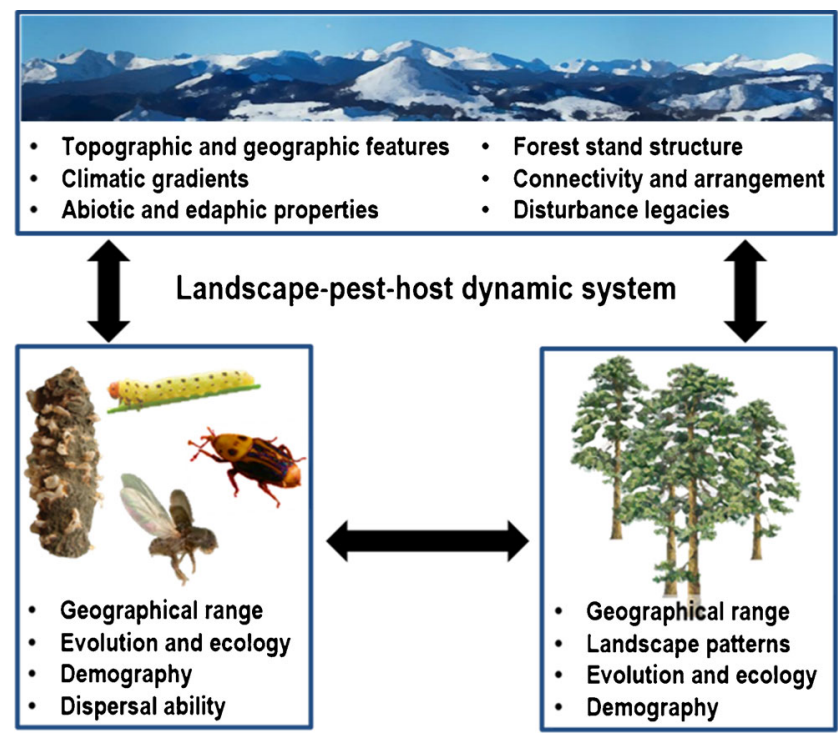

Fig. 2 Conceptual diagram of the interactions among landscape factors (top panel), forest-pest populations (lower left panel), and their primary host species (lower right panel). Landscape factors with clear influences on biotic interactions include, but are not limited to: (1) topographical and geographical effects on local/regional climates and abiotic environments, (2) variation in edaphic properties that can affect forest stand structure and tree health, (3) formation of natural barriers or connections which influence the movement of organisms, and (4) legacies of past forest disturbances 
genomics, making them features of the landscape affecting forest pest dynamics [22, 23].

\section{Pests and Landscape Features at Multiple Scales}

The success of pests depends upon finding suitable hosts within environments conducive to reproduction and survival [17, 18]. As a result, the realized ranges of forest pests are often smaller than the full range of their hosts $[8,17]$. These mismatches are often dictated by landscape features which becomes apparent in spatiotemporal patterns of pest occurrence [17]. A number of abiotic and biotic landscape features have been linked to forest-pest dynamics. These features interact to create a complex and temporally dynamic mosaic of pest outbreak risk. Considered at small to large scales these factors range from variation in host-tree phenotypes, to local edaphic properties (e.g., soil texture, depth, moisture), forest stand attributes (e.g., tree composition, density, stand size, fragmentation, isolation, ratio of edge to interior), topographical characteristics (e.g., slope, aspect, and elevation), up to regional effects of climate and land-use history. Physical aspects of the landscape can affect pest distribution, particularly those features that impede pest movement such as mountain ranges, bodies of water, or areas lacking a sufficient number of host trees [17-19]. In the case of exotic pests, locations with higher introduction rates, such as key shipping harbors, can lead to spatially aggregated ranges as illustrated by the higher concentration of exotic forests pests linked to points of entry in the northeastern USA compared to the rest of the country [24].

Within forest stands, tree species composition, abundance, and diversity can have dramatic influences on pest dynamics. High tree diversity or just the presence of particular species of non-host trees at threshold abundances can disrupt host selection of insect pests by complicating chemical signals used as cues for locating hosts [25-31]. Tree composition can also play a role in pest dynamics that is independent of species diversity and density. For example, the spread of beech bark disease (a pest-complex of the introduced scale insect Cryptococcus fagisuga and one of two canker fungi) in the eastern USA does not appear to be linked to overall density of American beech (Fagus grandifolia), but infections are more common in stands where beech is the dominant species [32].

Host tree density has long been assumed to be a dominant driver of pest outbreaks, particularly within conifer forests where high tree density can lead to increased mortality during bark beetle epidemics [33-36]. Tree density can also affect defoliating insects on hardwoods. For example, higher host density promotes faster population growth and shorter intervals between gypsy moth (Lymantria dispar) outbreaks [37]. However, the influence of tree density on overall mortality risk from all sources in a forest stand may vary across environmental gradients, such as elevation, as illustrated in California's
Sierra Nevada mixed conifer forests where high density stands suffer lower mortality at higher elevations, but greater mortality at lower elevations than low density stands [14]. Globally there appears to be an elevational gradient in cycles of defoliating insect pests in hardwood forests, even over relatively modest elevational ranges $(\leq 500 \mathrm{~m})$, whereby mid-elevations suffer more frequent outbreaks [38]. This gradient has been linked not only to mid-elevational peaks in host tree density, but also to shifts in natural enemy abundance patterns and changes in leaf quality across elevation $[38,39]$. However, further efforts to unravel the interactive effects of tree density and species composition is warranted, as studies across environmental gradients remain rare, but are much needed to shed light on the effects of environmental change on forest ecosystems.

Landscape factors such as soil characteristics, topography, elevation, and overall position strongly influence tree species distributions and abundances - attributes of stand structure that play an obvious role in pest outbreak risk and movement $[17,30]$. For example, survival of larval pine processionary moths (Thaumetopoea pityocampa) is linked to characteristics of the soils in which they pupate [40], making soil properties an important influence on defoliation risk over time. Spatial patterns in forest stand structure due to historical land-use, variable disturbances effects (e.g., fire intensity across slopes and aspects), and forest responses to management over time (e.g., rates of regrowth, changes in species abundance patterns) can have strong legacy effects on pest dynamics. For example, many pests are influenced by levels of forest fragmentation, stand size, patch arrangement on the landscape, and the ratio of edge to interior area - all of which are shaped by disturbance and management legacies at both spatial and temporal scales [41, 42]. Forest fragmentation and regrowth generate complex spatial and age structures among stands, thereby promoting outbreak patterns in relation to the physical arrangement and age of trees found within forest stands [30, $43,44]$. Further, stand arrangement and topography play important roles in the spread of pests, as seen in the influence of spatial proximity to rivers and streams on the spread of Phytophthora ramorum, the causal agent of sudden oak death (SOD), in tanoaks (Notholithocarpus densiflorus) of Oregon, USA [45]. Also, during outbreaks of larch budmoths (Zeiraphera diniana), traveling waves of dispersing moths form in relation to landscape spatial attributes, with subsequent direction and rate of spread determined by the size of obstacles to movement (e.g., areas with little to no suitable habitat) and connectivity of suitable habitat $[46,47]$.

\section{Landscape Interactions with Climate and Atmosphere}

Forest location on the landscape in relation to physical features can have substantial influence on pest populations, often 
through landscape interactions with atmospheric conditions. These interactions not only affect local environments, but also rates of climate change and deposition of airborne pollutants which can affect pest populations via impacts on their physiology and ranges, or through impacts on host trees. For example, in managed tree line forests of the Swiss Alps, mortality of Swiss pine (Pinus cembra) from infections by the pathogenic snow fungi Gremmeniella abietina and Phacidium infestans increase with later snow melt and earlier snow melt, respectively, with melt date linked to natural variation in site topography, aspect, and elevation [48]. Landscape position can influence concentrations and deposition of atmospheric pollution through effects of elevational and urban-rural gradients which in turn generates gradients in host tree susceptibility to pests. For example, elevational gradients in ozone concentration and levels of nitrogen deposition strongly affect pine tree mortality from bark beetles in forest stands of the San Bernardino Mountains which are downwind and upslope of Los Angeles, California, USA [49]. These gradients can be significant as evidence indicates that increasing temperatures can interact with atmospheric concentrations of $\mathrm{CO}_{2}$ and ozone $\left(\mathrm{O}_{3}\right)$ to either increase, or decrease the outbreak risk of defoliating insects depending on moderating effects of host-tree defensive-chemistry [12]. Finally, pest dispersal among host populations can be influenced by local and regional wind patterns, effectively creating higher and lower risk stands through wind effects on the direction and rate of pest movement [30, 50].

Influences of landscape features on pest dynamics through impacts of weather and climate are illustrated by the role of historical climate patterns in dictating forest pest range limits at higher elevations and latitudes. [6, 7, 51-53]. Importantly, warming temperatures and drought are not felt evenly across the Earth's surface, a situation directly linked to complicated effects of landscape features on local to global climate. For example, an equivalent amount of atmospheric warming across elevational and latitudinal gradients translates into a greater proportional change when comparing low versus high latitudes/elevations, as illustrated by stronger responses of the mountain pine beetle (Dendroctonus ponderosae) to changing climates at higher elevations and latitudes $[8,11,52,53]$. Given the pervasive nature of climate change, and the severity of climate model predictions for many forested regions, there is a pressing need to fill significant gaps in our understanding of how global change factors will interact with landscape features to affect forest pest dynamics at multiple spatiotemporal scales [7-9]. Climatically-driven mismatches in the ranges and phenology of host trees and pest, or strong climatic limitation on the development and survival of pests are common mechanisms excluding pests from portions of their hosts' ranges [54]. As global climate change alters the strength of these mechanisms in complex ways, numerous forest insects and pathogens have expanded their ranges into higher latitude and higher elevation forests with negative consequences for their tree hosts $[6-12,52,53,55]$. For example, sub-Arctic birches (Betula spp.) have been subjected to recent bouts of high-intensity defoliation from several Geometrid moth species that have expanded their ranges as warming temperatures allow for synchrony between moth and leaf development [55].

Currently, the likelihood of pest range expansion and outbreaks are commonly assessed via climate-based models utilizing anticipated changes in temperature (e.g., [52]). While this is indeed a useful approach, it can fail to capture additional controls on pest species' ranges and movement such as shifting precipitation patterns, interactions with competitors, pressures from natural enemies, host tree health, and dispersal polymorphisms that can slow niche tracking-factors that greatly influence pest establishment and responses to environmental change $[56,57]$. Also, climate change will not only impact pest development and survival, but will also increase environmental stresses on trees, particularly in relation to landscape features that amplify warm, dry conditions such as: rain-shadows, sun-exposed aspects, well-drained soils and slopes, and lower elevation/latitude extents of ranges [7-13, 58-60]. For example, rates and severity of mortality of quaking aspen trees ( $P$. tremuloides) due to damage from Trypophloeus populi (aspen bark beetle), Agrilus liragus (bronze poplar borer), and Cytospora fungi are greater on southerly slopes and in lower elevational stands of southwestern USA [61, 62]. At the same time, spatial similarity in annual precipitation patterns can influence the risk of pest infestations, as in the example of gypsy moth $(L$. dispar) outbreak synchrony with regional precipitation of northeastern USA hardwood forests [63]. Finally, additional global change factors can simultaneously promote novel disturbance regimes (e.g., invasive annual grasses increasing fire risk) and novel biotic interactions with exotic forest pests $[6-8,52,53]$. These factors are certain to interact with landscape features and processes generating a complex array of pest outbreak risk that will require extensive cross-scale, interdisciplinary investigation.

\section{Tree Phenotypes as Landscape Features}

Both deciduous and coniferous trees can possess formidable defenses or resistance mechanisms that enable some individuals to withstand damage from natural enemies even during severe pest epidemics [64-72]. Mounting evidence verifies that tree defenses are genetically controlled and shaped by selection pressures adapting trees to local conditions [73-79]. Thus, a range of abiotic and biotic interactions, including pest activity, can exert strong selection on spatial patterns of tree phenotypes not only within stands, but also at continental scales $[64,68,69,72]$. These patterns, both contemporary and historical, shape pest evolution and behavior 
with consequences for their population dynamics. At the same time, genetic and environmental influences often interactively determine tree defenses [73, 74, 76], and some pest species are greatly influenced by host defenses while others are more strongly influenced by environmental conditions. For example, gall-forming aphids of the genus Adelges were more strongly influenced by tree genetics, while those of the genus Sacchiphantes were more strongly influenced by environmental factors when attacking Norway spruce (Picea abies) in common gardens in different climatic zones of Sweden [75]. Pests can also rapidly adapt to their natal host tree phenotypes, resulting in poor fitness on alternate hosts or even on genetically differentiated hosts of the same species reducing rates of spread or host switching (e.g., [80]).

Variation in tree defenses at a landscape scale are often associated with resource gradients or environmental characteristics such as local soil properties [73-76, 81]. As a result, variation in abiotic properties can generate striking patterns in host susceptibility when viewed across climatic and edaphic gradients associated with landscape features [73, 74, 82]. For example, factors affecting tree growth rates, such as nutrient or water availability linked to topographic features and position have been repeatedly shown to influence anti-pest defenses, as illustrated by slower growing and drought-stressed pines producing fewer resin ducts throughout their stems, increasing their susceptibility to bark beetles $[64,68,71,82$, 83]. Historical disturbance regimes can also influence contemporary levels of tree defense against pests. For example, higher historical frequencies of low intensity fires are correlated to greater resin duct defenses in ponderosa pines (Pinus ponderosa) of the Rocky Mountains, USA [71]. Strikingly, the combined influences of pest communities, resource gradients, and historical disturbance regimes are hypothesized to have led to phylogenetically conserved differences in tree defenses at continental scales. For example, high latitude and Nearctic species of pines (Pinus) have greater levels of constitutive defenses compared to their lower latitude and Palaearctic counterparts [84, 85], while oaks (Quercus) display a global pattern of decreasing defenses with increasing latitude (i.e., less defenses in colder locations) [86].

Defenses within individual trees can change over time in relation to tree ontogeny and physiology, generally leading to greater susceptibility to natural enemies as trees age with some exceptions. Changes in defenses with increasing age have also been reported to occur within tissues of the same tree-e.g., older stem material (trunk) is less defended against pests than younger stem material (mid- to upper-stem) in lodgepole pines (Pinus contorta) [87], while needles on white spruce (Picea glauca) tend to grow more defended with age [88]. When forest stands are viewed collectively across larger spatial scales, age-related changes in defenses against pests lead to spatial patterns in stand-level susceptibility across different disturbance and management histories [30, 42]. Thus, understanding the complexity of pest dynamics requires efforts to unravel the controls on tree defenses and host selection, along with linking forest pathology to landscape factors varying on temporal scales (Fig. 3).

Beyond tree defenses, variation in tree phenotypic traits can result in different responses to stresses within and among tree species with cascading consequences for susceptibility to pests and disturbances [21, 89]. Adaptive phenotypes arise in response to landscape features as illustrated by the contrasting drought-response strategies of redwood species growing across precipitation gradients [90], and by large latitudinal gradients in cold tolerance of tree species in North American forests [3]. Also, several widespread and ecologically important tree genera (e.g., Populus, Quercus) vary in ploidy (chromosome sets per cell) across environmental gradients [61]. Variation in ploidy of trees and herbaceous plants has been linked to differences in niche breadth, drought tolerance, antiherbivore defenses, and adaptability to environmental change [91-93]. For example, triploidy in quaking aspens (Populus tremuloides) appears to adapt trees to warmer landscape

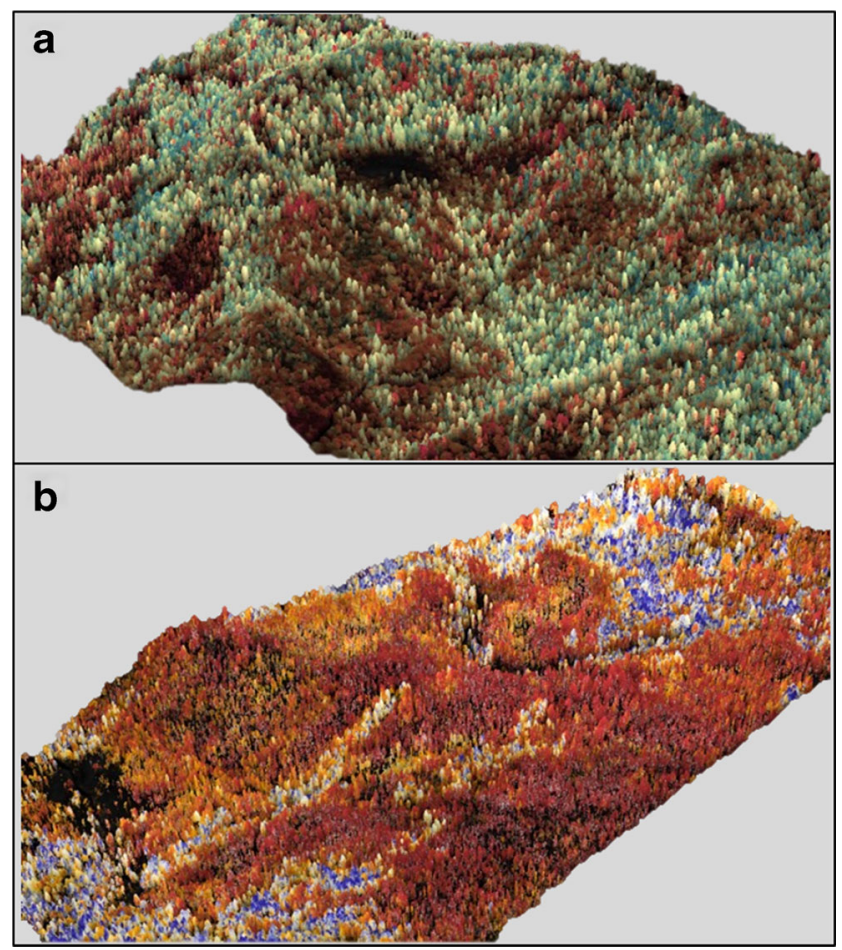

Fig. 3 Landscape features influence tree stress, potentially increasing interactions with pests that advantageously attack stressed hosts, and generating spatially aggregated patterns of pest activity. For example, trees on southern aspects and well-drained slopes often experience drought stresses before trees growing in areas less prone to amplify drought conditions. Here, remote LIDAR-hyperspectral imaging shows patterns of (a) mixed-severity and (b) high-severity drought stress related in part to slope and aspect variation within forests of the Sierra Nevada, California, USA (image courtesy of Greg Asner). Darker red indicates trees experiencing greater drought stress, while green and blue colors indicate healthier trees 
positions, but may also predispose trees to environmental stress and pests as illustrated in areas experiencing rapid aspen mortality [61]. Understanding the influences of tree phenotypic traits on pest dynamics will require greater application of continually advancing genomic approaches at a landscape scale.

\section{Case Study 1: Jack Pine Budworm}

Jack pine budworm (Choristoneura pinus pinus) is a native moth that primarily defoliates jack pine (Pinus banksiana) during its larval stage. The value in taking a landscape approach to understanding budworm outbreaks is found in studies considering the influence of ratios of forest edge to the interior area of stands of the North American Great Lakes region. Viewed at smaller spatial/temporal scales, there appears to be both a positive and negative effect of increasing edge-area ratios on budworm defoliation of jack pines. When examined over a range of stand structures and a longer time span, a shift in edge to area effects on budworm activity over the temporal course of outbreaks explains these competing patterns [94]. Further, this shift in edge effects is driven in part by budworm preference for host trees with greater abundance of male (pollen) cones than those trees with a greater abundance of female cones - a finding that illustrates the strong mechanistic role of selection on host phenotypes and forest stand structure at larger spatial scales. In this case, the distribution of pine tree phenotypes that are preferred by budworms are not randomly distributed within forest stands during or after jack pine budworm outbreaks. Instead, pines are found structured within stands in relation to the interactions among insect outbreak history, stand age (older trees produce more pollen cones), and synchronized spatial patterns of pollen cone production across the landscape [95].

\section{Case Study 2: White Pine Blister Rust}

Landscape features have been repeatedly implicated in the likelihood of infection and tree mortality by the introduced fungal-pathogen white pine blister rust (Cronartium ribicola) in North American five-needle pines (subgenus Strobus). Blister rust infection appears to be related to biophysical factors, such as seasonal weather and temperature difference related to mountain topography [96]. Mortality from blister rust is greater in islands of conspecific trees (low species diversity) growing in wetter microclimates, but also on steep slopes exposed to high winds - likely due to higher passive dispersal rates onto these slopes [34, 96-99]. When viewed at a larger scale, the location of these topographic microsites with higher risk of blister rust infection also depend on regional climate, possibly due to physiological differences dictating realized niches across genetically variable populations of blister rust. For example, greater rates of infection have been found on both south- and north-facing slopes to the east and west of the Continental Divide, respectively [34, 96], and at cooler, higher latitudes in the Great Lakes Region [97]. Additionally, rust-resistant phenotypes are present in various five-needle pine species. While these phenotypes tend to occur at relatively low abundances, their frequency within populations changes across the landscape, with overall susceptibility to blister rust varying at latitudinal and longitudinal scales. Resistant phenotypes remain under intense investigation, but at present geographical patterns suggest a positive association among rust resistance and drought tolerance suggesting the possibility of enhanced resistance in trees adapted to dry sites [100].

\section{Case Study 3: Bark Beetles}

Large, multiyear epidemics of bark beetles have increased rates of tree mortality across European and North American forests $[15,16]$. While bark beetles of the genera Ips, Dendroctonus, and Scolytus have received a large amount of research, the landscape scales of recent epidemics have led to a much improved understanding of their spatiotemporal spread. At local scales, bark beetles selectively attack less defended trees [64] and following host selection are unable to kill trees with greater numbers or sizes of resin ducts [68, 71]. Beetles are also unable to successfully mass attack trees that have little bark texture which acts as an anatomical defense mechanism [69]. Tree defenses are controlled through a combination of growth traits, edaphic factors, and genetics $[73,74,77,82]$ which are strongly influenced by landscape features. Forest stand structure is a strong determinant of bark beetle outbreak risk [33, 101]. For example, activity of the mountain pine beetle (Dendroctonus ponderosae) is greater in fragmented forest stands in early temporal stages of outbreaks, while more continuous forest stands become infested as beetles reach epidemic levels. Across forests, host-tree basal area and age have been linked to the likelihood of bark beetle infestation. For example, greater pine tree basal area was a strong predictor of $D$. ponderosae outbreaks of the Rocky Mountains, USA [34, 35] and the occurrence of various bark beetle species in pines and firs of the Sierra Nevada, California, USA [36]. Similar effects of basal area and tree size have been reported for Ips typographus outbreaks in spruces of European forests [101-103]. Forest stand aspect, slope, and elevation influence bark beetle activity and outbreak risk, with apparent variation in the effects of these variables over the course of Ips typographus outbreaks [101]. Finally, at very large spatiotemporal scales, bark beetle outbreaks have strong correlations to climate trends, specifically spatial patterns of warming $[8,11,52]$ and drought that are enhanced by landscape features and position $[8,104]$. 


\section{Conceptualizing Landscape Influences on Forest Pest Dynamics}

Our quantitative understanding of pest dynamics at landscape scales has improved rapidly in recent years due to advances in remote sensing technologies (e.g., Fig. 3), genomics techniques, and improved statistical and spatial models. Despite these advances, global change pressures are increasingly interacting with landscape features to alter an already complex mosaic of pest-outbreak risk and tree mortality (Figs. 1, 2, and 3). These complexities have the potential to make associations among landscape features and pests seem highly idiosyncratic when considered across pest-host groups with divergent functional and life history traits. This issue can complicate our ability to interpret how landscape features influence forests pests and lead to uncertainty and difficulty in generalizing findings across studies and spatiotemporal scales. As a step toward resolving this complexity, I offer a conceptual framework aimed at understanding how pest functional traits influence landscape-scale dynamics independent of environmental and land-use transitions (Fig. 4).

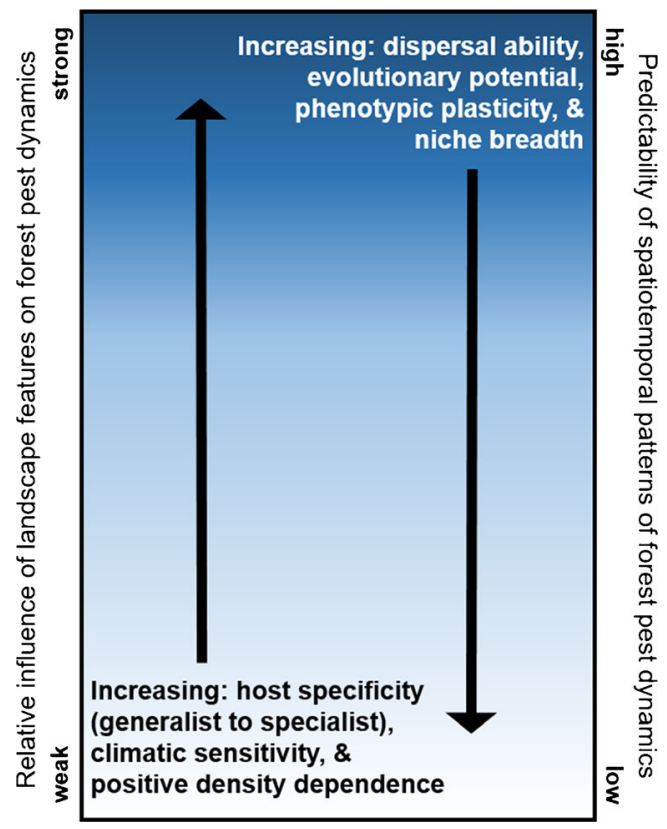

Fig. 4 A conceptual model linking pest traits to their hypothesized effects on the relative influence of landscape features on forest pest dynamics (left vertical axis) and the predictability of spatiotemporal patterns of pest activity (right vertical axis). Traits are divided among those with positive associations (i.e., as levels of the trait increase, the influence of landscape features on pest dynamics likely increase) and negative associations (i.e., as levels of the trait increase, the influence of landscape features decrease) with the relative influence of landscape features on pests dynamics. Positive associative traits are shown on the left half of the figure, negative on the right half. Traits shown can interact to increase or decrease the relative influence of landscape features, such that multiple traits from the positive and negative associative groups can be found within the same pest
The relative influence of landscape features on forest pest dynamics and the predictability of spatiotemporal patterns in forest pest populations is dictated by numerous factors (Fig. 4). For example, pests with high dispersal ability and rates are more likely to establish across landscape boundaries than are pests with less dispersal capability, reducing the relative influence of landscape features on their dynamics [17-19, 45-47, 57]. Similarly, increasing levels of phenotypic plasticity and greater niche breadth can serve to decrease the influence of landscape features such as climatic gradients and fragmented patterns of hosts by allowing pests to cross environmental conditions and host types $[72,75]$. On a longer temporal scale, greater evolutionary potential can also reduce landscape influences on pests by allowing continual adaptation, the generation of cryptic species, or the promotion of wide geographic ranges.

Influence of landscape features on pest dynamics are likely to increase alongside increasing climatic sensitivity and positive density dependence (e.g., Moran effect, allee effect) [10, $63,83]$. Levels of host specificity (i.e., generalists to specialists) can increase the role of landscape features on pests as they track the position of an increasingly constrained group of hosts, while feeding strategies can drive pest responses to landscape scale factors. For example, a meta-analysis of phytophagous insect responses to drought-stressed plants found a majority of insects were negatively impacted by plant water stress [105]. Furthermore, this negative association among plant stress and insect performance occurred across all major feeding guilds with the exception of stem and leaf borers. Not surprisingly, wood and bark boring beetles are often the most destructive forest pests, particularly during drought in temperate forests $[15,16]$. However, a limited number of studies of pest responses to drought-stress from forested ecosystems are available, leaving it unclear how insect pests from different feeding guilds or across levels of host-specialization will respond to global change stresses on hosts, particularly in the face of adaptive forest management strategies which are likely to favor some pest feeding strategies over others [106].

\section{Conclusion}

Forest pest dynamics are influenced by landscape features and the relationship of these features to forest disturbance legacies and environmental gradients $[107,108]$. Thus, we can expect pest activity to grow increasingly complicated with continued species introductions, and climate and land-use change. A pathway toward improved understanding and predictive models of forest pest dynamics likely lies in a framework that incorporates pest species' functional traits with those of their hosts to allow cross-scale quantification and scaling of pest outbreak risk [109]. Ideally this framework will grow increasingly empirical, utilize genomic-based trait information, and 
focus on testing explicit hypotheses regarding causal linkages among pest traits and their outbreak risk in relation to landscape features. Some of these traits, such as dispersal rates and climatic sensitivity, are already commonly used in models of pest dynamics with great success $[37,38,41,42,47,50,52$, $57,63]$. However, exploring additional influence on pest dynamics is a key for increasingly accurate, cross-scale predictions of both pest risk and tree susceptibility in an era of rapid change. Being able to predict the likelihood of mortality at small spatial scales or even individual trees, for example, would be an enormously useful advance in forest management, particularly in forests (e.g., western North American montane and sub-alpine forests) where intervention is currently often limited to mechanical thinning and prescribed fire, increasing the value of targeted modeling approaches for understanding the effects of specific landscape features on the dynamics of forest pests.

Acknowledgments I thank Phil van Mantgem, Jeffry Mitton, and Akasha Faist for comments on early drafts, and Mark Norris and one anonymous reviewer for insights that improved this review. I am indebted to Greg Asner for contributing aerial hyperspectral images and Jeffry Mitton for landscape photos used in figures.

\section{Compliance with Ethical Standards}

Conflict of Interest The author states that there is no conflict of interest.

\section{References}

1. Boyd IL, Freer-Smith PH, Gilligan CA, Godfray HCJ. The consequence of tree pests and diseases for ecosystem services. Science. 2013;342(6160):1235773.

2. Flower CE, Gonzalez-Meler MA. Responses of temperate forest productivity to insect and pathogen disturbances. Annu Rev Plant Biol. 2015;66:547-69.

3. Hawkins BA, Rueda M, Rangel TF, Field R, Diniz-Filho JAF. Community phylogenetics at the biogeographical scale: cold tolerance, niche conservatism and the structure of North American forests. J Biogeogr. 2014;41(1):23-38.

4. Feng G, Mi X, Eiserhardt WL, Jin G, Sang W, Lu Z et al. Assembly of forest communities across East Asia-insights from phylogenetic community structure and species pool scaling. Scientific reports, 2015. 5.

5. Franklin JF, Shugart HH, Harmon ME. Tree death as an ecological process. BioScience. 1987; 550-56.

6. Allen CD, Breshears DD, McDowell NG. On underestimation of global vulnerability to tree mortality and forest die-off from hotter drought in the Anthropocene. Ecosphere. 2015;6(8), art129.

7. Anderegg WR, Hicke JA, Fisher RA, Allen CD, Aukema J, Bentz $\mathrm{B}$, et al. Tree mortality from drought, insects, and their interactions in a changing climate. New Phytol. 2015;208(3):674-83.

8. Raffa KF, Aukema BH, Bentz BJ, Carroll AL, Hicke JA, Turner $\mathrm{MG}$, et al. Cross-scale drivers of natural disturbances prone to anthropogenic amplification: the dynamics of bark beetle eruptions. Bioscience. 2008;58(6):501-17.
9. Weed AS, Ayres MP, Hicke JA. Consequences of climate change for biotic disturbances in North American forests. Ecol Monogr. 2013;83(4):441-70.

10. Battipaglia G, Büntgen U, McCloskey SP, Blarquez O, Denis N, Paradis L, et al. Long-term effects of climate and land-use change on larch budmoth outbreaks in the French Alps. Clim Res. 2014;62:1-14.

11. Creeden EP, Hicke JA, Buotte PC. Climate, weather, and recent mountain pine beetle outbreaks in the western United States. For Ecol Manag. 2014;312:239-51.

12. Kollberg I, Bylund H, Jonsson T, Schmidt A, Gershenzon J, Björkman C. Temperature affects insect outbreak risk through tritrophic interactions mediated by plant secondary compounds. Ecosphere. 2015;6(6), art102.

13. Meddens AJ, Hicke JA, Macalady AK, Buotte PC, Cowles TR, Allen CD. Patterns and causes of observed piñon pine mortality in the southwestern United States. New Phytol. 2015;206(1):91-7.

14. Van Gunst KJ, Weisberg PJ, Yang J, Fan Y. Do denser forests have greater risk of tree mortality: A remote sensing analysis of densitydependent forest mortality. For Ecol Manag. 2016;359:19-32.

15. Kärvemo S, Van Boeckel TP, Gilbert M, Grégoire JC, Schroeder M. Large-scale risk mapping of an eruptive bark beetle-importance of forest susceptibility and beetle pressure. For Ecol Manag. 2014;318:158-66.

16. Hicke JA, Meddens AJ, Kolden, CA. Recent tree mortality in the Western United States from Bark Beetles and Forest Fires. For Sci. 2015.

17. Holdenrieder O, Pautasso M, Weisberg PJ, Lonsdale D. Tree diseases and landscape processes: the challenge of landscape pathology. Trends Ecol Evol. 2004;19(8):446-52.

18. Plantegenest M, Le May C, Fabre F. Landscape epidemiology of plant diseases. J R Soc Interface. 2007;4(16):963-72.

19. Meentemeyer RK, Haas SE, Václavík T. Landscape epidemiology of emerging infectious diseases in natural and human-altered ecosystems. Annu Rev Phytopathol. 2012;50:379-402.

20. Keeley JE. Ecology and evolution of pine life histories. Ann For Sci. 2012;69(4):445-53.

21. Talluto MV, Benkman CW. Conflicting selection from fire and seed predation drives fine-scaled phenotypic variation in a widespread North American conifer. Proc Natl Acad Sci U S A. 2014;111:9543-8.

22. Sork VL. Gene flow and natural selection shape spatial patterns of genes in tree populations: implications for evolutionary processes and applications. Evol Appl. 2016;9(1):291-310.

23. Schwartz MK, McKelvey KS, Cushman SA, Luikart G. Landscape genomics: a brief perspective. In Spatial complexity, informatics, and wildlife conservation. Japan: Springer; 2010. p. 165-74.

24. Liebhold AM, McCullough DG, Blackburn LM, Frankel SJ, Von Holle B, Aukema JE. A highly aggregated geographical distribution of forest pest invasions in the USA. Divers Distrib. 2013;19(9):1208-16.

25. Jactel H, Brockerhoff EG. Tree diversity reduces herbivory by forest insects. Ecol Lett. 2007;10(9):835-48.

26. Jactel H, Birgersson G, Andersson S, Schlyter F. Non-host volatiles mediate associational resistance to the pine processionary moth. Oecologia. 2011;166(3):703-11.

27. Dulaurent A-M, Porté AJ, van Halder I, Vétillard F, Menassieu P, Jactel H. Hide and seek in forests: colonization by the pine processionary moth is impeded by the presence of nonhost trees. Agric For Entomol. 2012;14:19-27.

28. Hantsch L, Braun U, Scherer-Lorenzen M, Bruelheide H. Species richness and species identity effects on occurrence of foliar fungal pathogens in a tree diversity experiment. Ecosphere. 2013;4(7), art81. 
29. Rigot T, van Halder I, Jactel H. Landscape diversity slows the spread of an invasive forest pest species. Ecography. 2014;37(7): 648-58.

30. Sturtevant BR, Cooke BJ, Kneeshaw DD, MacLean DA. Modeling insect disturbance across forested landscapes: insights from the spruce budworm. In Simulation modeling of forest landscape disturbances. Springer International Publishing; 2015. pp. 93-134.

31. Castagneyrol B, Régolini M, Jactel H. Tree species composition rather than diversity triggers associational resistance to the pine processionary moth. Basic Appl Ecol. 2014;15(6):516-23.

32. Morin RS, Liebhold AM, Tobin PC, Gottschalk KW, Luzader E. Spread of beech bark disease in the eastern United States and its relationship to regional forest composition. Can J For Res. 2007;37(4):726-36.

33. Fettig CJ, Klepzig KD, Billings RF, Munson AS, Nebeker TE, Negrón JF, et al. The effectiveness of vegetation management practices for prevention and control of bark beetle infestations in coniferous forests of the western and southern United States. For Ecol Manag. 2007;238(1):24-53.

34. Cleaver CM, Jacobi WR, Burns KS, Means RE. Limber pine in the central and southern Rocky Mountains: stand conditions and interactions with blister rust, mistletoe, and bark beetles. For Ecol Manag. 2015;358:139-53.

35. Nelson KN, Rocca ME, Diskin M, Aoki CF, Romme WH. Predictors of bark beetle activity and scale-dependent spatial heterogeneity change during the course of an outbreak in a subalpine forest. Landsc Ecol. 2014;29(1):97-109.

36. Walker RF, Swim SL, Fecko RM, Johnson DW, Miller WW. Bark beetle demography in Sierra Nevada mixed conifer: variability and influencing factors. For Res. 2015;4(147):2.

37. Haynes KJ, Liebhold AM, Johnson DM. Spatial analysis of harmonic oscillation of gypsy moth outbreak intensity. Oecologia. 2009;159(2):249-56.

38. Haynes KJ, Liebhold AM, Johnson DM. Elevational gradient in the cyclicity of a forest-defoliating insect. Popul Ecol. 2012;54(2): 239-50.

39. Erelli MC, Ayres MP, Eaton GK. Altitudinal patterns in host suitability for forest insects. Oecologia. 1998;117(1-2):133-42.

40. Dulaurent AM, Porté AJ, van Halder I, Vétillard F, Menassieu P, Jactel $\mathrm{H}$. A case of habitat complementation in forest pests: pine processionary moth pupae survive better in open areas. For Ecol Manag. 2011;261(6):1069-76.

41. James PM, Fortin MJ, Sturtevant BR, Fall A, Kneeshaw D. Modelling spatial interactions among fire, spruce budworm, and logging in the boreal forest. Ecosystems. 2011;14(1):60-75.

42. Robert LE, Kneeshaw D, Sturtevant BR. Effects of forest management legacies on spruce budworm (Choristoneura fumiferana) outbreaks. Can J For Res. 2012;42(3):463-75.

43. Régolini M, Castagneyrol B, Dulaurent-Mercadal AM, Piou D, Samalens JC, Jactel H. Effect of host tree density and apparency on the probability of attack by the pine processionary moth. For Ecol Manag. 2014;334:185-92.

44. Lantschner MV, Corley JC. Spatial pattern of attacks of the invasive Woodwasp Sirex noctilio, at Landscape and Stand Scales. 2015.

45. Peterson E, Hansen E, Kanaskie A. Spatial relationship between Phytophthora ramorum and roads or streams in Oregon tanoak forests. For Ecol Manag. 2014;312:216-24.

46. Sherratt JA, Lambin X, Sherratt TN. The effects of the size and shape of landscape features on the formation of traveling waves in cyclic populations. Am Nat. 2003;162(4):503-13.

47. Johnson DM, Bjørnstad ON, Liebhold AM. Landscape geometry and travelling waves in the larch budmoth. Ecol Lett. 2004;7(10): 967-74.
48. Barbeito I, Brücker RL, Rixen C, Bebi P. Snow fungi-induced mortality of Pinus cembra at the alpine treeline: evidence from plantations. Arct Antarct Alp Res. 2013;45(4):455-70.

49. Jones ME, Paine TD, Fenn ME, Poth MA. Influence of ozone and nitrogen deposition on bark beetle activity under drought conditions. For Ecol Manag. 2004;200(1):67-76.

50. Anderson DP, Sturtevant BR. Pattern analysis of eastern spruce budworm Choristoneura fumiferana dispersal. Ecography. 2011;34(3):488-97.

51. Battisti A, Stastny M, Netherer S, Robinet C, Schopf A, Roques $\mathrm{A}$, et al. Expansion of geographic range in the pine processionary moth caused by increased winter temperatures. Ecol Appl. 2005;15(6):2084-96.

52. Bentz BJ, Régnière J, Fettig CJ, Hansen EM, Hayes JL, Hicke JA, et al. Climate change and bark beetles of the western United States and Canada: direct and indirect effects. Bioscience. 2010;60(8): 602-13.

53. Mitton JB, Ferrenberg SM. Mountain pine beetle develops an unprecedented summer generation in response to climate warming. Am Nat. 2012;179(5):E163-71.

54. van Asch M, Visser ME. Phenology of forest caterpillars and their host trees: the importance of synchrony. Annu Rev Entomol. 2007;52:37-55.

55. Jepsen JU, Kapari L, Hagen SB, Schott T, Vindstad OPL, Nilssen $\mathrm{AC}$, et al. Rapid northwards expansion of a forest insect pest attributed to spring phenology matching with sub-Arctic birch. Glob Chang Biol. 2011;17:2071-83.

56. Early R, Sax DF. Climatic niche shifts between species' native and naturalized ranges raise concern for ecological forecasts during invasions and climate change. Glob Ecol Biogeogr. 2014;23(12): $1356-65$

57. Robinet C, Liebhold AM. Dispersal polymorphism in an invasive forest pest affects its ability to establish. Ecol Appl. 2009;19(7): 1935-43.

58. Gustafson EJ, De Bruijn AM, Pangle RE, Limousin JM, McDowell NG, Pockman WT, et al. Integrating ecophysiology and forest landscape models to improve projections of drought effects under climate change. Glob Chang Biol. 2015;21(2): 843-56.

59. Kane JM, Kolb TE, McMillin JD. Stand-scale tree mortality factors differ by site and species following drought in southwestern mixed conifer forests. For Ecol Manag. 2014;330:171-82.

60. Liang E, Leuschner C, Dulamsuren C, Wagner B, Hauck M. Global warming-related tree growth decline and mortality on the north-eastern Tibetan plateau. Clim Chang. 2016;134(1-2):16376.

61. Mock KE, Callahan CM, Islam-Faridi MN, Shaw JD, Rai HS, Sanderson SC, et al. Widespread triploidy in western North American aspen (Populus tremuloides). PLoS One. 2012;7(10): e48406.

62. Marchetti SB, Worrall JJ, Eager T. Secondary insects and diseases contribute to sudden aspen decline in southwestern Colorado, USA. Can J For Res. 2011;41(12):2315-25.

63. Haynes KJ, Bjørnstad ON, Allstadt AJ, Liebhold AM. Geographical variation in the spatial synchrony of a forestdefoliating insect: isolation of environmental and spatial drivers. Proc R Soc Lond B Biol Sci. 2013;280(1753):20122373.

64. Kane JM, Kolb TE. Importance of resin ducts in reducing ponderosa pine mortality from bark beetle attack. Oecologia. 2010;164:601-9. doi:10.1007/s00442-010-1683-4.

65. King JN, Alfaro RI, Lopez MG, Van Akker L. Resistance of Sitka spruce (Picea sitchensis (Bong.) Carr.) to white pine weevil (Pissodes strobi Peck): characterizing the bark defence mechanisms of resistant populations. Forestry. 2011;84:83-91. doi:10. 1093/forestry/cpq047. 
66. Moreira X, Alfaro RI, King JN. Constitutive defenses and damage in Sitka spruce progeny obtained from crosses between white pine weevil resistant and susceptible parents. Forestry. 2012;85:87-97.

67. Dardeau F, Deprost E, Laurans F, Lainé V, Lieutier F, Sallé A. Resistant poplar genotypes inhibit pseudogall formation by the wooly poplar aphid, Phloeomyzus passerinii Sign. Trees. 2014;28(4):1007-19.

68. Ferrenberg S, Kane JM, Mitton JB. Resin duct characteristics associated with tree resistance to bark beetles across lodgepole and limber pines. Oecologia. 2014;174(4):1283-92.

69. Ferrenberg S, Mitton JB. Smooth bark surfaces can defend trees against insect attack: resurrecting a 'slippery' hypothesis. Funct Ecol. 2014;28:837-45. doi:10.1111/1365-2435.12228.

70. Schoettle AW, Sniezko RA, Kegley A, Burns KS. White pine blister rust resistance in limber pine: evidence for a major gene. Phytopathology. 2014;104(2):163-73.

71. Hood S, Sala A, Heyerdahl EK, Boutin M. Low-severity fire increases tree defense against bark beetle attacks. Ecology. 2015;96(7):1846-55.

72. Burke JL, Carroll AL. The influence of variation in host tree monoterpene composition on secondary attraction by an invasive bark beetle: Implications for range expansion and potential host shift by the mountain pine beetle. For Ecol Manag. 2016;359:5964.

73. Sampedro L, Moreira X, Zas R. Costs of constitutive and herbivore-induced chemical defences in pine trees emerge only under low nutrient availability. J Ecol. 2011;99(3):818-27.

74. Moreira X, Zas R, Solla A, Sampedro L. Differentiation of persistent anatomical defensive structures is costly and determined by nutrient availability and genetic growth-defence constraints. Tree Physiol. 2015;35(2):112-23.

75. Axelsson EP, Iason GR, Julkunen-Tiitto R, Whitham TG. Host genetics and environment drive divergent responses of two resource sharing gall-formers on Norway spruce: a common garden analysis. PLoS One. 2015;10(11), e0142257.

76. Rubert-Nason KF, Couture JJ, Major IT, Constabel CP, Lindroth $\mathrm{RL}$. Influence of genotype, environment, and gypsy moth herbivory on local and systemic chemical defenses in trembling aspen (Populus tremuloides). J Chem Ecol. 2015;41(7):651-61.

77. Westbrook JW, Walker AR, Neves LG, et al. Discovering candidate genes that regulate resin canal number in Pinus taeda stems by integrating genetic analysis across environments, ages, and populations. New Phytol. 2015;205:627-41.

78. Zinkgraf MS, Meneses N, Whitham TG, Allan GJ. Genetic variation in NIN1 and C/VIF1 genes is significantly associated with Populus angustifolia resistance to a galling herbivore, Pemphigus betae. J Insect Physiol. 2015;84:50-9.

79. Harper AL et al. Molecular markers for tolerance of European ash (Fraxinus excelsior) to dieback disease identified using Associative Transcriptomics. Sci Rep. 2016;6:19335. doi:10. 1038/srep19335.

80. Evans LM, Allan GJ, Shuster SM, Woolbright SA, Whitham TG. Tree hybridization and genotypic variation drive cryptic speciation of a specialist mite herbivore. Evolution. 2008;62(12):3027-40.

81. Endara MJ, Coley PD. The resource availability hypothesis revisited: a meta-analysis. Funct Ecol. 2011;25(2):389-98.

82. Ferrenberg S, Kane JM, Langenhan JM. To grow or defend? Pine seedlings grow less but induce more defences when a key resource is limited. Tree Physiol. 2015;35(2):107-11.

83. Gaylord ML, Kolb TE, Pockman WT, Plaut JA, Yepez EA, Macalady AK, et al. Drought predisposes piñon-juniper woodlands to insect attacks and mortality. New Phytol. 2013;198(2): 567-78.

84. Moreira X, Mooney KA, Rasmann S, Petry WK, Carrillo-Gavilán A, Zas R, et al. Trade-offs between constitutive and induced defences drive geographical and climatic clines in pine chemical defences. Ecol Lett. 2014;17(5):537-46.

85. Carrillo-Gavilán A, Moreira X, Zas R, Gonzalez-Voyer A, Vilà M, Sampedro L. Phylogenetic and biogeographical patterns in defensive strategies and quantitative allocation to chemical defences in Palaearctic and Nearctic pine trees. J Biogeogr. 2015;42(4):684-93.

86. Pearse IS, Hipp AL. Global patterns of leaf defenses in oak species. Evolution. 2012;66(7):2272-86.

87. Goodsman DW, Lusebrink I, Landhäusser SM, Erbilgin N, Lieffers VJ. Variation in carbon availability, defense chemistry and susceptibility to fungal invasion along the stems of mature trees. New Phytol. 2013;197(2):586-94.

88. Quiring DT. Rapid change in suitability of white spruce for a specialist herbivore, Zeiraphera canadensis, as a function of leaf age. Can J Zool. 1992;70(11):2132-8.

89. Mezquida ET, Benkman CW. Causes of variation in biotic interaction strength and phenotypic selection along an altitudinal gradient. Evolution. 2014;68:1710-21.

90. Ambrose AR, Baxter WL, Wong CS, Næsborg RR, Williams CB, Dawson TE. Contrasting drought-response strategies in California redwoods. Tree Physiol. 2015;35(5):453-69.

91. Hao GY, Lucero ME, Sanderson SC, Zacharias EH, Holbrook NM. Polyploidy enhances the occupation of heterogeneous environments through hydraulic related trade-offs in Atriplex canescens (Chenopodiaceae). New Phytol. 2013;197(3):970-8.

92. Thompson KA, Husband BC, Maherali H. Climatic niche differences between diploid and tetraploid cytotypes of Chamerion angustifolium (Onagraceae). Am J Bot. 2014;101(11):1868-75.

93. Münzbergová Z, Skuhrovec J, Maršík P. Large differences in the composition of herbivore communities and seed damage in diploid and autotetraploid plant species. Biol J Linn Soc. 2015;115(2):270-87.

94. Radeloff VC, Mladenoff DJ, Boyce MS. The changing relation of landscape patterns and jack pine budworm populations during an outbreak. Oikos. 2000;90:417-30. doi:10.1034/j.1600-0706. 2000.900301.x.

95. Hughes JS, Fortin MJ, Nealis V, Régnière J. Pollen cone production in jack pine: spatial and temporal patterns subject to natural disturbance by the jack pine budworm. Can J For Res. 2013;44(3): 195-211.

96. Larson ER. Influences of the biophysical environment on blister rust and mountain pine beetle, and their interactions, in whitebark pine forests. J Biogeogr. 2011;38(3):453-70.

97. White MA, Brown TN, Host GE. Landscape analysis of risk factors for white pine blister rust in the mixed forest province of Minnesota, U.S.A. Can J For Res. 2002;32:1639-50.

98. Smith EK, Resler LM, Vance EA, Carstensen LW, Kolivras KN. Blister rust incidence in treeline whitebark pine, Glacier National Park, USA: Environmental and topographic influences. Arct Antarct Alp Res. 2011;43:107-17.

99. Smith-Mckenna EK, Resler LM, Tomback DF, Zhang H, Malanson GP. Topographic influences on the distribution of white pine blister rust in Pinus albicaulis treeline communities. Ecoscience. 2013;20(3):215-29.

100. Vogan PJ, Schoettle AW. Selection for resistance to white pine blister rust affects the abiotic stress tolerances of limber pine. For Ecol Manag. 2015;344:110-9.

101. Sproull GJ, Adamus M, Bukowski M, Krzyżanowski T, Szewczyk J, Statwick J, et al. Tree and stand-level patterns and predictors of Norway spruce mortality caused by bark beetle infestation in the Tatra Mountains. For Ecol Manag. 2015;354:261-71.

102. Mezei P, Grodzki W, Blaženec M, Škvarenina J, Brandýsová V, Jakuš R. Host and site factors affecting tree mortality caused by the spruce bark beetle (Ips typographus) in mountainous conditions. For Ecol Manag. 2014;331:196-207. 
103. Grodzki W, Starzyk JR, Kosibowicz M. Impact of selected stand characteristics on the occurrence of the bark beetle Ips typographus (L.) in the Beskid Żywiecki Mountains. For Res Pap. 2014;75(2):159-69.

104. Hart SJ, Veblen TT, Eisenhart KS, Jarvis D, Kulakowski D. Drought induces spruce beetle (Dendroctonus rufipennis) outbreaks across northwestern Colorado. Ecology. 2014;95(4):930-9.

105. Huberty AF, Denno RF. Plant water stress and its consequences for herbivorous insects: a new synthesis. Ecology. 2004;85(5):1383-98.

106. Björkman C, Bylund H, Nilsson U, Nordlander G, Schroeder M. Effects of new forest management on insect damage risk in a changing climate. Clim Chang Insect Pests. 2015. 248.
107. Beh MM, Metz MR, Seybold SJ, Rizzo DM. The novel interaction between Phytophthora ramorum and wildfire elicits elevated ambrosia beetle landing rates on tanoak, Notholithocarpus densiflorus. For Ecol Manag. 2014;318:21-33.

108. Keane RE, Loehman R, Clark J, Smithwick EA, Miller C. Exploring interactions among multiple disturbance agents in forest landscapes: simulating effects of fire, beetles, and disease under climate change. In Simulation modeling of forest landscape disturbances. Springer International Publishing, 2015. pp. 201-31.

109. Carmona CP, de Bello F, Mason NW, Lepš J. Traits without borders: integrating functional diversity across scales. Trends Ecol Evol. 2016;31:382-94. 